\title{
On the Bacteria from the Decomposing Fish Fillets.
}

\author{
Yukio GoTo.
}

There are not so many studies of the bacteria which decompose the fish muscle. HunTER ${ }^{(4)}$ isolated from the decomposing salmon, Colon-cloaca group, Bact aikaligenes, Bact. formosum-like bacteria and pigment producing bacteria. HildebrandT ${ }^{(6)}$ isolated from the putrefying fish, aerobic, motile, partly spore forming bacteria, but not an anaerobic. BECKER ${ }^{(2)}$ observed that the bacteria found in putrefying fish were aerobic gelatin-liquefying bacteria besides coccus, diprocoscus, short or long rods. FELLERs ${ }^{(3)}$ obtained cocci, sporulating aerobes, aerobic asporogenous chromatic rods, aerobic asporogenous achromogenic rods, yeasts, obligate anaerobes and spirilla from the decomposing salmon. HuLphen's) isolated ten kinds of bacteria from putrefying fish and observed that these bacteria were short oval, gram negative bacteria (partly gelatin liquefied) and micrococcus. HARRIsos ${ }^{t 5}$ found in decomposing fish muscle a number of Achromobacter which were probably marine bacteria (Micrococcus, Flavobacterium, Pseudomonas) with the ability to decompose the fish muscle. SchönBerg ${ }^{(6)}$ reported that the most encountered bacteria in the putrefying fish muscle were the rods, gram negative, slender, very active motile, gèlatin liquefying and best flourishing at room temperature.

Most of the authors above mentioned isolated the bacteria from the putrefying raw fish, the kinds of these being different according to their origins. The present paper embodies my observations on the bacteria found on fish fillets obtained from Tokyo fish market.

Experimental methods. The fillets of the following kinds of fish were obtained from the fish market from time, to time throughout a year, namely, Limanda, Thunnus orientalis, Trachurus japonicus, Scomber japonica, Cyprinus carpio, Pagrosomus major, Onchorhynchus keta, Stromateoides argenteus, Kareius bicoloratus, Scombrops loops, Parathunnus sibi, Seriola quinqueradiata, Scomber tapeinocephalus. A bit of each fish fillet (ca. 10gr.) was placed in a petri's dish at room temperature. Generally a very unpleasant odour was emitted 2 or 3 days afterwards. The surface of the fillet was covered with a faint white film and the bottom side of the fillet discharged some quantity of mucous liquid. Then the isolation was carried as usual from the surface and the mucous liquid using theagar plate shake culture, when the production of unpleasant odour became very strong.

The cultures were incubated for about 7 days at $25^{\circ} \mathrm{C}$. and $37^{\circ} \mathrm{C}$. in an nerobic and an unaerobic state. 
Mostly there appeared a few kinds of aerobic bacteria at $25^{\circ} \mathrm{C}$.

The culture media used are as follows:-1) Broth medium with $1 \%$ Liebig meat extract, $1 \%$ Witte pepton, 0.5\% natrium chloride; 2) Broth gelatin, formed by adding $15 \%$ gelatin to the broth medium; 3) Broth agar, 1.5\% agar to the broth medium; 4) Dunham's solution; 5) starch agar medium, $0.2 \%$ soluble starch to the broth agar; 6) Nitrate medium, $0.5 \%$ sodium nitrate to the broth medium; .7) Fermentation medium, 0.5\% respective suger to the broth medium; 8) Potato medium.

Description. The bacteria obtained are described and classified according to the systems of Bergey (1). In spite of reference to the works of MiguLA, Lehmann and NeUmanN, some bacteria could not be furnished with specific names, for which the letters $A, B, C$, etc. stand in the following list.

No. 1. Pseudomonas chloraphis (Guignard and Sauvageau) Bergejetal. 8 str.

No. 2. Pseudomonas ovalis (Ravenel) chester. 8 str.

No. 3. Pseudomonas fuorescens (Flügge) Migula 1 str.

No. 4. Pseudomonas 4 . 9 str.

Morphology. Rods; $06-0.8$ by 1.0-2.5 $\mu$ with rounded ends, occurring singly and in pairs and in short chains. Motile' possessing polar flagella. Gram-neg.

Cultural features. Gelatin colonies: circular, translucent, flat, grumose, entire, rapid liquefaction. Gelatin stab: crateriform or stratiforml iquefaction. Agar colonies: circular, transparent, smooth, raised or convex, coarsly or finely granular. Agar slant: filiform (or with auriculate edge), transparent, glistening. Medium assumes greenish fluorescence. Broth: turbid with pericle and sediment, becoming yellowish green, greenish fluorescence. Potato: faint yellowish cinnamon.

Physiological characters. Litmus milk: slightly acid, coagulated and peptonized weakly. Indol: not formed. Nitrate: not reduced. Starch: not hydrolysed. Aerobic: facultative. Opt. temp : $25^{\circ}-30^{\circ} \mathrm{O}$.

It resembles $P$. schnylkilliensis in many respects. However, it differs in the indol formation, the optimum temperature and the cultural features of gelatin colonies. (1) p. 165 .

No. 5. Achromobacter A. 2 str.

Morphology. Rods : 0.7 by 1.0-2.0 $\mu$, occurringsingly and in chains. Motile, with peritrichous flagella. Gram negative.

Cultural'features. Gelatin colonies: translucent, circular, concave, entire granular, crateriform liquefaction. Gelatin stab: stratiform liquefaction. Agar colonies: irregular, spreading (effuse), greenish gray, smooth, lobate, grumose, translucent. Agar slant: gray spreading, effuse, glistening, translucent. Broth: turbid with thin pellicle and sediment. Potato: no growth.

Physiological characters. Litmus milk: slow acid, coagulated, peptonized. Indol: formed (trace). Nitrate: reduced to nitrires. Dextrose and sucrose: acid and gas formed. Starch: not hydrolysed. Aerobic: Facultative. Opt. temp.: $25^{\circ}-30^{\circ} \mathrm{C}$.

It differs from A. Iitoralis in respects of indol production, nitrate reduction and milk culture reaction. It is thought to be situated near $A$. litoralis. It resembles $A$. coadunatum in respect of cultural features. It differs however, in the arrangements of flagella, growth on potato and the reduction of nitrates. (1) P. 205,215 .

No. 6. Achromobacter B. 1 str.

Morphology. Rods: 0.7 by $1.2 \sim 2.5 \mu$, occurring singly and in pairs, motile, with polar flagella. Gram negative.

Cultural features. Gelutin colonies: circular, flat, entire or undulate, amorphous or rosulate. Gelatin stab: filiform, no liquefaction. Agar colonies: circular, smooth, raised, gray, trans- 
parent, entire, finely or coarsly granular. Agar slant: filif̧orm flat or raised, glistening, smooth, transparent. Broth: turbid with sediment. Potato: thick, moist, glistening, cream yellow.

- Physiological characters Litmus milk: acid, coagulated. Indol: not formed. Nitrates: reduced to nitrites. Dextrose, sucrose, and lactose: acid formed. Aerobic: facultative. Opt. temp.: $25^{\circ}-30^{\circ} \mathrm{C}$.

It resembles A. ambigunin in respect of cultural features. However, it differs in the arrangements of flagella, reduction of nitrates, formation of indol and optimum temperature. (1) P. 219 .

No. 7. Achromobacter C. 1 str.

Morphology. Rods: $0.7-0.8$ by 1.2-25 $\mu$ occurring singly, with rounded ends. Motile with single polar flagellum. Gram negative.

Cultural features. Gelatin colonies: circular, coneave, entire, finely granular. Crateriform liquefaction. Gelutin stab: crateriform liquefaction. Agar colonies: circular, smooth, brownish gray, flat or raised, entire, finely granular. Medium assumes slightly brownish. Agar slant: filiform, flat, glistening, smooth, transparent, dark gray, medium assumes slightly brownish. Broth: turbid with sediment. Potato: thick, moist, glistening, brilliant reddish orange.

Physiological charactes \&. Litmus milk: alkaline, peptonized. Litmus reduced very quickly. Indol: not formed. Nitrates: reduced to nitrites. Dextrose: acid formed. Aerobic: facultative. Opt. temp.: $25^{\circ}-30^{\circ} \mathrm{C}$.

It resembles $A$. geniculatum in respects of cultural features. However, it differs in the reduction of nitrates and growth on potato. (1) P. 213.

No. 8. Achromobacter D. 4 str.

Morphology. Rods: $0.5-0.7$ by $0.7-2.0 \mu$, short rods, occurring singly and in pairs. Motile with polar flagella. Gram negative.

Cultural features. Gelatin colonies : circular, translucent, entire, granular, crateriform liquefaction. Gelatin stab: rapid liquefaction, stratiform or infundibuliform. Agar colonies: irregular, myceroid or rhizoid (radiated), raised, opaque, gray, smooth, finely or coarsely granular, auriculate. Agar slant: Gray, filiform (spreading) smooth, moist, raised, glistening. Medium assumes slight brownish colour. Broth: turbid with slight pellicle and flocculent sediment. Potato: cream yellow, moist, spreading, thick glistening. Medium assumes slightly gray.

Physiological characters. Litmus milk: acid reaction with soft coagulum. Slow peptonization. Indol: not formed. Nitrates: reduced to nitrites. Starch: not hydrolysed. Dextrose and Sucrose : acid formed but gas formed or not. Aerobic: facultative. Opt. temp.: $25^{\circ}-30^{\circ} \mathrm{C}$.

It differs from any one of motile flagella polar, gelatin liquefying Achromobacter, in respects of cultural features and also from $A$. multistriatum in the reduction of nitrates. (1) P. 198.

No. 9. Achromobacter E. 4 str.

Morphology. Rods: $0.6-0.7$ by 1.0-2.5 $\mu$, occurring singly and in pairs. Motile with one to four polar flagella. Gram negative.

Cullural features. Gelatin colonies; spot, flat, entire, finely granular, no liquefaction. Gelatin stab: villous growth, liquefaction succate (14 days). Agar colonies: circular or amoeboid, whitish, flat or convex, entire, smooth, translucent to opaque, coarsely or finely granular. Agar slant: filiform, raised, smooth, translucent. Broth: turbid with thin pellicle and gray sediment; Potato: yellowish gray, moist spreading.

Physiological characters. Litmus milk: becoming acid slowly. Indol: not formed. Nitrates: reduced to nitrites. Starch: not hydrolysed. Dextrose and sucrose: acid and gas formed. Aerobic: facultative, Opt. temp.: $25^{\circ} \mathrm{C}$.

It differs from No. 8 in the form of cultural features.

No. 10. Achromobacter multislriatum (wright) Bergey et al. 9 str.

No. 11. Achromobacter F. 1 str.

Morphology. Rods: $0.6-0.7$ by $1.0-2.0 \mu$, oceurring singly and in pairs. Motile with one to three polar flagella. Gram negative. 
Cultural features. Gelatin colonies: small circular, gray. Gelatin stab: no liquefaction. villous growth. Agar colonies: irregular, spieading, translucent, smooth, flat or effuse, auriculate, finely granular. Agar slant: spreading, flat or effuse, smooth, glistening, translucent. Broth: turbid with reticulose pellicle and sediment. Potato: thin, moist, pinkish gray to dirty orange.

Physiologica? characters. Litmus milk: alkaline reaction. Indol; not formod. Nitrates: reduced to nitrites. (weak). Dextrose: weak acid formed. Aerobic: facultative. Opt. temp.: 25 $-30^{\circ} \mathrm{C}$.

It is thought that it must be situated near A. sinosum. It differs however, in respects of milk culture reaction, reduction of nitrates, formation of indol and in severel cultural features. (1) P. 216.

No. 12. Achromobactar $G$. 2 str.

Morphology. Rods; $0.6-0.8$ by 1.1-2.5 $\mu$, with rounded end, oceurring singly, in pairs, and in short chains. Motile, possessing polar flagella. Gram negative.

Cullural features. Gelatin colonies: Small circular, smooth, flat or raised, entire, amorphous or finely granular. Gelatin stab: no liquefaction. Filiform growth. Agar colonies: circular, smooth, raised or convex, gray, entire, granular. Agar stant: Filiform, raised, smooth, glistening, transparent, gray. Broth: turbid with slight pellicle and sediment. Potato: thick, glistening, dark orange or yellowish brown.

Physiological characters. Limtmus milk: weak acid reaction or no change. Indol: not formed. Nitrates: not reduced. Dextrose: acid formed. Starch: not hydrolysed. Aerobic; facultative. Opt. temp.: $85^{\circ} \mathrm{C}$.

It resembles $A$. sinosum and $A$. ambiguum in respect of liquefaction of gelatin and growth on potato. But it differs in the features of the gelatin colonies and the formation of indol. (1) p. 215,219 .

No. 13. Achromobacter H. 2 str.

Morphology. Rods : $0.6 \sim 0.7$ by $1.2 \sim 2.0 \mu$, oceurring singly and in pairs (and in short chains), rounded ends. Non motile. Gram negative.

Cultural features. Gelatin colonies: small circular, gray. Gelatin stab: no liquefaction. Filiform growth. Agar colonies: circular, smooth, convex, gray, transparent, finely granular. Agar slant: filiform or echinulate, smooth, raised, gray, opaque, glistening. Broth: turbid with slight pellicle and sediment. Polato: orange yellow, thick, glistening. Medium assumes dark gray.

Physiological characters. Litmus milk: unchanged. Indol: not formed. Nitrates: not reduced. Starch: not hydrolysed. Dextrose, Sucrose and lactose: acid not formed. Aerobic: facultative. Opt. temp.: $25^{\circ} \sim 30^{\circ} \mathrm{C}$.

It has many resemblances to A. luminosum in respects of physiological characters. But it differs in the formation of indol and cultural features. It is not seen to emit luminescence. (1) p. 226 .

No 14. Flavobacterium A, 1. str.

Morphology: Rods: $0.7 \sim 0.8$ by $1.2-2.0 \mu$, rounded ends, occurring singly and in pairs. Motile with polar flagellum. Gram negative.

Cultural features. Gelatin colonies: small circular, raised, brilliant orange yellow, entire, amorphous. Gelatin stab: no liquefaction. filiform growth. Agar colonies: irregular, spreading, effuse, smooth, undulate, translucent, yellowish gray. Agar slant: filiform, flat or raised, glistening, smooth, translucent, yellowish gray. Broth: turbid with slight pellicle and sediment. Potato: moist, dark orange yellow, raised, spreading. Medium assumes dark gray.

Physiologucal characters. Litmus milk: alklaine. Indol: not formed. Nitrates : reduced to nitrites. Starch: nothydrolysed. Dextrose, and sucrose: acid formed. Opt. ternp.: $25^{\circ}-30^{\circ} \mathrm{C}$.

It resembles $F$. turcosum in respects of growth on potato, reaction of milk and formation of indol. But it differs in cultural features and in reduction of nitrates. (1) p. 144.

No. 15. Elavobacterium cerviseae (Fuhrman) Bergey et al. 1 str. 
No. 16. Serratia marcescens Bizio. 1 str.

No. 17. Kurthia zophii (Kurth) Trevisan. $3 \mathrm{str}$.

No. 18. Micrococeus A. 1 str.

Morphology. Spheres: $0.7 \sim 1.0 \mu$ dia, occurring singly, in pairs and in irregular clumps. Gram positive.

Cultural features. Gelatin colonies: circular, smooth, entire. Gelatin stab: saccate or infundibuliform liquefaction. Agar colonies: circular, white, glistening, convex, or pulvinate, smooth, entire, amorphous or finely granular. Agar slant: filiform, white, raised or convex, glistening, smooth, opaque. Broth: turbid with white sediment, no pellicle, Potato: white streak glistening.

Physiological characters. Litmus milk: acid reaction. Indol: not formed. Nitrates: reduced to nitrites. Starch: not hydrolysed. Dextrose and sucrose : acid formed. Opt. temp. . $25^{\circ}-30^{\circ} \mathrm{C}$.

In the genus Micrococcus which does not produce chromogenesis and liquefies gelatin, there are only three species $M$. freudenreichis, $M$. cremoris-viscosi, $M$. saccatus known, but this culture is quite different from these three. (1) p. 86.

No. 19. Achromobacter middletownit (Conn) Bergey et al. 2 str.

No 20. Flavobacterium lutescens (Lustig) et al. 1 str.

No. 21. Bacillus subtilis (Ehrenberg) Cohn. 1 str.

To determine whether the above isolated bacteria grow well on fish fillet and produce an unpleasant odour or not, a piece of fish fillet (ca. $10 \mathrm{gr}$.) obtained antiseptically was inoculated with the above bacteria after ascertaining it was aseptic by keeping at $25^{\circ} \mathrm{C}$. for 24 hours. By this test, it was clear that every one of these grows well on fish fillet and produces an umpleasant odour.

Summary. (1) Throughout a year in all seasons, 21 species werc isolated as significant, selecting from among 63 cultures, from various kinds of fish fillets obtained from Tokyo fish market. (2) All of them flourished best at $25^{\circ}-30^{\circ} \mathrm{C}$, and except 5 cultures, they were gram negative, slender, active motile rods with rounded ends. (3) No obligate anaerobe could be isolated. (4) There was only one spore forming bacterium. (5) Of these, 26 cultures were found to be the members of Pseudomonas group, 28 to be the members of Achromobacter group, 3 belong to Flavobacterium, 1 to Kurthia, 1 to Serratia, 1 to Micrococcus and 1 to Bacillus. (6) All of these bacteria grow well on fish fillet and produce an unpleasant odour.

\section{Literature cited}

(1) Bengey: Determinative Bacteriology. Baltimore. 1930.

(2) Becker: Zeit. f. Fleisch a. Milchhygiene. 32 (13)-(21), 1922.

(3) Feliers: Abstract of Biology: I, 12590, 1926.

(4) Hunter: J. Bact. 5 1920, p. 543

(5) SANBorn: J. Bact. 19 1930, p. 375--382.

(6) Scrösberg: Berliner Tierärztl. Wochenschritf. 26, 1930, S. 429. 